\title{
Football refereeing: Identifying innovative methods
}

\author{
Reza MohammadKazemi ${ }^{\mathrm{a}}$, Farnoosh Taherkhani ${ }^{\mathrm{b}^{*}}$, Heydar Soleymani $^{\mathrm{c}}$ and Mustafa Darvishi ${ }^{\mathrm{d}}$
}

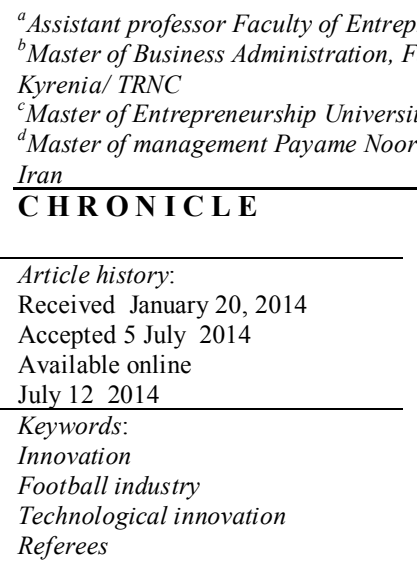

\begin{abstract}
The aim of the present study is to identify the potentials innovation in football industry. Data were collected from 10 national and international referees, assistant referees and referees' supervisors in Iran. In this study, technological innovations are identified that assist better refereeing performances. The analysis revealed a significant relationship between using new technologies and referees 'performance. The results indicate that elite referees, assistant referees and supervisors agreed to use new technological innovations during the game. According to their comments, this kind of technology causes the referees' performance development.
\end{abstract}

\section{Introduction}

Undeniably, Football is among the most attractive sports making it the most popular sport in the world. Indeed, the growth of football has influenced political, economic as well as social issues. At present, refereeing has found a specific and deterministic role in football. A referee has an important position in a football match, especially at a professional level in which one incorrect decision could lead to a downturn in economic fortunes of a club (Castagna et al., 2007). It is also important to deal with issues relating to incorrect decisions and the consequences of these decisions. Therefore, in order to enhance the standard and quality of officiating it is essential that referees are able to make use of available technology either, directly or indirectly (Collins, 2010). Since the 2010 World Cup in South Africa, and due to some mistakes at higher levels in this World Cup, there have been many discussions in international federation association endeavoring to convince convincing FIFA of the

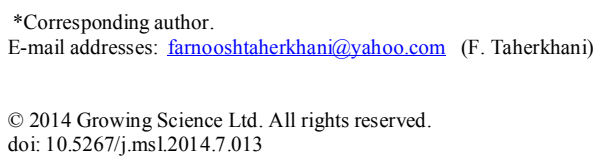


need to make use of available technology. According to Van Quaquebeke and Giessne (2010) many faults happening in football are vague and there is no clear-cut method to distinguish right or wrong.

Indisputably, reducing referees' mistakes make the role of technology and innovation much more necessary in the future. In other words, technology could play a vital role in referees' decisions and judgments. Utilizing adequate tools can help referees to judge more precisely. Gonzalez (2003) stated that using electronic systems could improve referees' performance during football match. The main objective in utilizing innovative technologies in formal football matches is to upgrade them due to referees' responsibilities; i.e., to establish fairness which is sometimes ignored. Recent decades have witnessed that innovation and revolution play an essential role in the sport industry (Ratten, 2011). Mullin et al. (2007), Schwarz et al. (2012), Ringuet-Riot et al. (2014) stated that innovation could play an essential role in sport. According to Turner and Shilbury (2010) technology is an essential attribute to many sports promotions. By building a new system, many opportunities can be provided for various sports clubs. Collins (2010) believes that the new technology should be introduced into refereeing and it is a way to make fair decisions.

Innovation has been defined in different ways by scientists and researchers. Schumpeter $(1928,1943)$ was the first person to examine innovation in industry. He expressed it as presenting a new combination of producing elements and various forms in one system, i.e., a function of a new product. He defined a successful innovation as performing an action exclusively, an action, which is not the product of mind or intelligence, but positively affects it. According to Ringuet-Riot et al. (2014), innovation is a complex construct, broadly defined "as the introduction of a new idea or behavior in the form of a technology, product, service, structure, system or process on to the market" (pp.137-149). Furthermore, Pierce and Delbecq (1977) defined innovation as establishing, absorbing and practicing a new idea or activity. Khalil (2004) believed in innovation as presenting a new product, service or a process to an organization. From his personal point of view, technology (or the product) should not necessarily be new, novel or unique. Schumpeter (1943) outlined five factors based on the output of innovation. 1) innovation in product, 2) innovation in a new process in industry, 3) innovation in the market, 4) innovation in supply network, and 5) innovation in an organization. Considering different ideas and definitions of innovation, three different types of innovation can be identified.

1- Radical innovation: it usually occurs based on invention or a scientific idea and it results in changes in new technology or industries (Henderson \& Clark, 1990).

2-Incremental innovation: these innovations are limited, but they have an effective role in improvements of a product, process or service (Henderson \& Clark, 1990).

3-Routine innovation: this is a mimicked innovation which is very limited (Dundon, 2002).

Ratten (2010) indicated that innovation in sport can be the consequence of changes in technology. Recently, the rapid increase in using technological innovations in sport has been the focus of several sport organizations and has resulted in seeking competitive advantage. Initially innovation accepted by those sports such as cycling and sailing as technology could easily take part to these sports functions. After that, during $20^{\text {th }}$ century, Sports scientists, swimming and track and field coaches were also support innovation to help their athletic to improve their performance in worldwide competitions. In addition, Great Britain also contributed to sport successful performance in the beginning of 20th century, particularly, in swimming coaching and incorporation of coaching in different fields of sport science (Ringuet-Riot et al., 2014).

General understanding of technology is a bit vague and it has been analyzed from different perspectives. Loland (2002) stated that technology is a tool that is made by man in order to achieve its goal, and then sport technology is made by human to help them to reach their goal, which is related 
to sport. He argues that given the nature of sport, technologies can play various functions. For example, one kind of sport technology can increase functionality, including new fast skin swimsuit for water friction reduction. Another form of technology includes helmets in ice hockey, which is designed for injuries prevention. The chance of using video cameras in assisting referees decisions are thought to promote justice.

Federation of International Football Associations (FIFA) has played a crucial role in developing football by taking some innovative measures. Sepp Blatter, FIFA President, stated that innovative technologies should be used to present a new model to promote referee's performance levels (CNN, 2010). Additionally, Lussier, and KimBall (2009) believed that the changes in football technology have been increasingly continued; the products, which were once imagined are coming into existence to prove their effectiveness. Each day indicates that variable technologies and innovations were increasing in the football industry (Atali \& Kursad, 2013).

According to Maruenda (2004), managing football by non-equipped eyes sounds impossible especially in cases when the ball has passed the goal line, which is effective in the final result. When decisions are made correctly, they are effective in the result. He claims that mistakes in adjudging offside are very common; investigating the situations of the player in offside and the situation of the defenders, all has to be considered by the referee. Eye movements, players' movements and the condition of the ball prevent the referee from making the right decision since the eyes and brain may not always recognize offside conditions in the instant the infraction occurs. There are still some key points about this concern, which need to be dealt with. Gonzalez (2003) indicates that innovations such as devices the referee's whistle or devices in linesmen's flags could allow referees to make their decisions faster and not to stop a match to review the video. The referees can make their judgments through the signs they receive by their whistles and flags electronically innovated equipment such as designing new whistles, flags, ground and ball can assist referees significantly. Therefore, practicing new technological devices and compounding them with audio-visual ones can assist referees much better in their decision making (Button et al., 2006).

\section{Method}

This study has utilized a qualitative approach. Data was collected from 10 national and international referees, assistant referees and referees' supervisors who have been working on Iran's football federation in the superior league. Statistical population was divided into three groups of national and international referees, linesmen and side judges. In this interview, Mr. Masoud Enayat, Yadu'llah Soleimani, Hatem Beck Poor, Alireza Rajablu, Naer Jafari. Abutaleb Tahirian, Ali Khosravi, Mohammad Fanaei, Golamreza Behravan and Ismail Safiri have participated. In this study, the final results are based on previous studies and interviews, and sampling is purposeful

\section{Findings and results}

Based on the research questions, four potential factors such as innovative ideas in football referees filed, sport technology in football referees filed, analyzing innovative idea in the football industry and technical analysis in football referees field have been proposed. Each proposed item contained 10 questions which are presented in the following. To make accurate decisions to whether confirm or reject these factors, it is necessary to use an appropriate statistical test. According to the purpose of the test and the low number of samples, binomial test have been used in this test.

\subsection{The potential factors of innovative ideas in football referees filed}

In short, 10 variables that may influence innovative idea on referees filed have been considered. Four factors including, identifying the need for innovation, analyzing the innovation, determining the 
performance requirement, suggesting the new ideas have been confirmed and 6 factors have been rejected. Detailed information, including the results of the survey is presented in the Table 1.

\section{Table 1}

Potential Factors of innovative ideas

\begin{tabular}{lccccc}
\hline Potential Factors & Number & $\min$ & $\max$ & Mean & Standard deviation \\
\hline Identifying the need for innovation & 10 & 5 & 4 & 4.3 & 0.483 \\
Identifying the value of Innovation in referee & 10 & 4 & 2 & 3.1 & 0.568 \\
Identifying the role of innovation in referee & 10 & 4 & 2 & 3.1 & 0.568 \\
Analyzing the innovation & 10 & 5 & 4 & 4.6 & 0.516 \\
Determining Performance requirement & 10 & 5 & 4 & 4.5 & 0.527 \\
Suggesting the new ideas & 10 & 5 & 4 & 4.8 & 0.422 \\
Identifying the innovation in related organizations & 10 & 3 & 1 & 1.9 & 0.568 \\
Supporting the new ide by mangers & 10 & 2 & 1 & 1.4 & 0.516 \\
Identifying the idea feasibility & 10 & 2 & 1 & 1.9 & 0.316 \\
Using new ideas in referee & 10 & 5 & 3 & 3.4 & 0.699 \\
\hline
\end{tabular}

In the following, each question has been examined by binomial test. The result presented in Table 2 .

Table 2

The result of Binomial test about innovative analysis

\begin{tabular}{|c|c|c|c|c|c|c|c|}
\hline Potential Factors & Groups & Classification & Number & $\begin{array}{c}\text { Observed } \\
\text { Prop } \\
\end{array}$ & $\begin{array}{l}\text { Test } \\
\text { Prop } \\
\end{array}$ & P-value & $\begin{array}{c}\text { The results of } \\
\text { potential factors }\end{array}$ \\
\hline $\begin{array}{l}\text { Identifying the need } \\
\text { for innovation }\end{array}$ & $\begin{array}{l}\text { Group1 } \\
\text { Total }\end{array}$ & $\leq 3$ & $\begin{array}{l}10 \\
10\end{array}$ & $\begin{array}{l}1.0 \\
1.0\end{array}$ & 0.6 & 0.000 & Confirm \\
\hline $\begin{array}{l}\text { Identifying the value } \\
\text { of Innovation in } \\
\text { referee }\end{array}$ & $\begin{array}{l}\text { Group1 } \\
\text { Group2 } \\
\text { Total }\end{array}$ & $\begin{array}{l}\leq 3 \\
>3\end{array}$ & $\begin{array}{c}2 \\
8 \\
10\end{array}$ & $\begin{array}{l}0.2 \\
0.8 \\
1.0\end{array}$ & 0.6 & 0.624 & Reject \\
\hline $\begin{array}{c}\text { Identifying the role } \\
\text { of innovation in } \\
\text { referee }\end{array}$ & $\begin{array}{l}\text { Group1 } \\
\text { Group2 } \\
\text { Total }\end{array}$ & $\begin{array}{l}\leq 3 \\
>3\end{array}$ & $\begin{array}{c}2 \\
8 \\
10\end{array}$ & $\begin{array}{l}0.2 \\
0.8 \\
1.0\end{array}$ & 0.6 & 0.107 & Reject \\
\hline $\begin{array}{l}\text { Analyzing the } \\
\text { innovation }\end{array}$ & $\begin{array}{l}\text { Group1 } \\
\text { Total }\end{array}$ & $\leq 3$ & $\begin{array}{l}10 \\
10\end{array}$ & 1.0 & 0.6 & 0.000 & Confirm \\
\hline $\begin{array}{l}\text { Determining } \\
\text { Performance } \\
\text { requirement }\end{array}$ & $\begin{array}{l}\text { Group1 } \\
\text { Total }\end{array}$ & $\leq 3$ & $\begin{array}{l}10 \\
10\end{array}$ & $\begin{array}{l}1.0 \\
1,0\end{array}$ & 0.6 & 0.000 & Confirm \\
\hline $\begin{array}{l}\text { Suggesting the new } \\
\text { ideas }\end{array}$ & $\begin{array}{l}\text { Group1 } \\
\text { Total }\end{array}$ & $\leq 3$ & $\begin{array}{l}10 \\
10\end{array}$ & $\begin{array}{l}1.0 \\
1.0\end{array}$ & 0.6 & 0.000 & Confirm \\
\hline $\begin{array}{c}\text { Identifying the } \\
\text { innovation in related } \\
\text { organizations }\end{array}$ & $\begin{array}{c}\text { Group2 } \\
\text { Total }\end{array}$ & $>3$ & $\begin{array}{l}10 \\
10\end{array}$ & $\begin{array}{l}1.0 \\
1.0\end{array}$ & 0.6 & 0.107 & Reject \\
\hline $\begin{array}{l}\text { Supporting the new } \\
\text { ide by mangers }\end{array}$ & $\begin{array}{l}\text { Group2 } \\
\text { Total }\end{array}$ & $>3$ & $\begin{array}{l}10 \\
10\end{array}$ & $\begin{array}{l}1.0 \\
1.0\end{array}$ & 0.6 & 0.107 & Reject \\
\hline $\begin{array}{l}\text { Identifying the idea } \\
\text { feasibility }\end{array}$ & $\begin{array}{l}\text { Group2 } \\
\text { Total }\end{array}$ & $>3$ & $\begin{array}{l}10 \\
10\end{array}$ & $\begin{array}{l}1.0 \\
1.0\end{array}$ & 0.6 & 0.107 & Reject \\
\hline $\begin{array}{l}\text { Using new ideas in } \\
\text { referee }\end{array}$ & $\begin{array}{l}\text { Group1 } \\
\text { Group2 } \\
\text { Total }\end{array}$ & $\begin{array}{l}\leq 3 \\
>3\end{array}$ & $\begin{array}{c}3 \\
7 \\
10\end{array}$ & $\begin{array}{l}0.3 \\
0.7 \\
1.0\end{array}$ & 0.6 & 0.322 & Reject \\
\hline
\end{tabular}

\subsection{The potential factors of sport technology in football referee filed}

In short, 10 variables that may influence sport technology on referees filed have been considered. Four factors including, determining the performance requirement, defining innovation technology, gaining required technology, determining technical goal have been confirmed and 6 factors have been rejected. Detailed information, including the results of the survey is presented in the Table 3. 
Table 3

The potential factor of sport technology

\begin{tabular}{lccccc}
\hline Potential factors & Number & Minimum value & Maximum value & Mean & Standard deviation \\
\hline To define a product & 10 & 1 & 4 & 2.4 & 0.966 \\
To determine performance requirements & 10 & 4 & 5 & 4.6 & 0.516 \\
To define productivity & 10 & 1 & 2 & 1.5 & 0.527 \\
To define innovation technology & 10 & 3 & 5 & 4.6 & 0.699 \\
To have necessary technical knowledge & 10 & 2 & 3 & 2.8 & 0.422 \\
To gain required technology & 10 & 4 & 5 & 4.8 & 0.422 \\
To determine technical goals & 10 & 4 & 5 & 4.3 & 0.483 \\
To compete in the product development & 10 & 1 & 2 & 1.3 & 0.483 \\
To have technology good & 10 & 1 & 3 & 1.8 & 0.632 \\
To have risk innovation capability & 10 & 1 & 3 & 1.5 & 0.707 \\
\hline
\end{tabular}

In the following, each question has been examined by binomial test and the results are presented in Table 4 as follows,

Table 4

The result of Binomial test about sport technology in football referee filed

\begin{tabular}{|c|c|c|c|c|c|c|c|}
\hline Potential factors & Groups & Classification & Number & $\begin{array}{l}\text { Observed } \\
\text { Prop }\end{array}$ & $\begin{array}{l}\text { Test } \\
\text { Prop }\end{array}$ & P-value & $\begin{array}{l}\text { The results of } \\
\text { potential factors }\end{array}$ \\
\hline \multirow{3}{*}{ To define a product } & Group1 & $\leq 3$ & 1 & 0.1 & \multirow{3}{*}{0.6} & \multirow{3}{*}{0.367} & \multirow{3}{*}{ Reject } \\
\hline & Group2 & $>3$ & 9 & 0.9 & & & \\
\hline & Total & & 10 & 1.0 & & & \\
\hline \multirow{2}{*}{ To determine performance requirements } & Group1 & \multirow{2}{*}{$\leq 3$} & 10 & 1.0 & \multirow{2}{*}{0.6} & \multirow{2}{*}{0.000} & \multirow{2}{*}{ Confirm } \\
\hline & Total & & 10 & 1.0 & & & \\
\hline \multirow{2}{*}{ To define productivity } & Group2 & \multirow{2}{*}{$>3$} & 10 & 1.0 & \multirow{2}{*}{0.6} & \multirow{2}{*}{0.107} & \multirow{2}{*}{ Reject } \\
\hline & Total & & 10 & 1.0 & & & \\
\hline \multirow{3}{*}{ To define innovation technology } & Group1 & $\leq 3$ & 7 & 0.7 & \multirow{3}{*}{0.6} & \multirow{3}{*}{0.006} & \multirow{3}{*}{ Confirm } \\
\hline & Group2 & $>3$ & 3 & 0.3 & & & \\
\hline & Total & & 10 & 1.0 & & & \\
\hline \multirow{2}{*}{ To have necessary technical knowledge } & Group 2 & \multirow{2}{*}{$>3$} & 10 & 1.0 & \multirow{2}{*}{0.6} & \multirow{2}{*}{0.107} & \multirow{2}{*}{ Reject } \\
\hline & Total & & 10 & 1.0 & & & \\
\hline \multirow{2}{*}{ To gain required technology } & Group1 & \multirow{2}{*}{$\leq 3$} & 10 & 1.0 & \multirow{2}{*}{0.6} & \multirow{2}{*}{0.000} & \multirow{2}{*}{ Confirm } \\
\hline & Total & & 10 & 1.0 & & & \\
\hline \multirow{2}{*}{ To determine technical goals } & Group1 & \multirow{2}{*}{$\leq 3$} & 10 & 1.0 & \multirow{2}{*}{0.6} & \multirow{2}{*}{0.000} & \multirow{2}{*}{ Confirm } \\
\hline & Total & & 10 & 1.0 & & & \\
\hline \multirow{2}{*}{ To compete in the product development } & Group2 & $>3$ & 10 & 1.0 & 0.6 & 0.107 & Reiect \\
\hline & Total & $>3$ & 10 & 1.0 & 0.6 & 0.101 & \\
\hline To have technology good & Group2 & $>3$ & 10 & 1.0 & 0.6 & 0.107 & Reject \\
\hline & Total & & & 1.0 & & & \\
\hline To have risk innovation capability & Group2 & $>3$ & 10 & 1.0 & 0.6 & 0.107 & Reject \\
\hline & Total & $>3$ & 10 & 1.0 & & & \\
\hline
\end{tabular}

\subsection{Potential factor of analysis innovative idea in the football industry}

In short, 10 variables that may influence innovative idea on referees filed have been considered. Four factors including, analyzing opportunities, analyzing current demand, analyzing future demand and analyzing sports industry have been confirmed and 6 factors have been rejected. Detailed information, including the results of the survey is presented in Table 5.

Table 5

Potential factors of analysis innovative idea in the football industry

\begin{tabular}{|c|c|c|c|c|c|}
\hline Potential factors & Number & Min & Max & Mean & Standard deviation \\
\hline To analyze rivals & 10 & 1 & 1 & 1.0 & 0.000 \\
\hline To analyze potential customers & 10 & 1 & 2 & 1.3 & 0.483 \\
\hline To analyze the treat & 10 & 1 & 2 & 1.6 & 0.516 \\
\hline To analyze opportunity & 10 & 4 & 4 & 4.0 & 0.000 \\
\hline To analyze current demands & 10 & 4 & 5 & 4.9 & 0.316 \\
\hline To analyze future demand & 10 & 5 & 5 & 5.0 & 0.000 \\
\hline To analyze sports industry & 10 & 4 & 5 & 4.2 & 0.422 \\
\hline To analyze current treat & 10 & 2 & 3 & 2,1 & 0.316 \\
\hline To analyze technology products & 10 & 1 & 3 & 2.2 & 0.632 \\
\hline To analyze creativity in related organization & 10 & 1 & 3 & 1.3 & 0.675 \\
\hline
\end{tabular}


In the following, each question has been examined by binomial test. The result presented in Table 6

Table 6

The result of Binomial test about analyzing the innovative idea in football industry

\begin{tabular}{|c|c|c|c|c|c|c|c|}
\hline Potential factors & Group & Classification & Numbers & $\begin{array}{l}\text { Observed } \\
\text { Prop }\end{array}$ & Test Prop & P-value & $\begin{array}{c}\text { The results of } \\
\text { potential factors }\end{array}$ \\
\hline To analyze rivals & $\begin{array}{c}\text { Group } 2 \\
\text { Total }\end{array}$ & $>3$ & $\begin{array}{l}10 \\
10\end{array}$ & $\begin{array}{l}1.0 \\
1.0\end{array}$ & 0.6 & 0.107 & Reject \\
\hline To analyze potential customers & $\begin{array}{c}\text { Group2 } \\
\text { Total }\end{array}$ & $>3$ & $\begin{array}{l}10 \\
10\end{array}$ & $\begin{array}{l}1.0 \\
1.0\end{array}$ & 0.6 & 0.107 & Reject \\
\hline To analyze the treat & $\begin{array}{c}\text { Group } 2 \\
\text { Total }\end{array}$ & $>3$ & $\begin{array}{l}10 \\
10\end{array}$ & $\begin{array}{l}1.0 \\
1.0\end{array}$ & 0.6 & 0.107 & Reject \\
\hline To analyze opportunity & $\begin{array}{c}\text { Group } 1 \\
\text { Total }\end{array}$ & $\leq 3$ & $\begin{array}{l}10 \\
10\end{array}$ & $\begin{array}{l}1.0 \\
1.0\end{array}$ & 0.6 & 0.000 & Confirm \\
\hline To analyze current demands & $\begin{array}{l}\text { Group } 1 \\
\text { Total }\end{array}$ & $\leq 3$ & $\begin{array}{l}10 \\
10\end{array}$ & $\begin{array}{l}1.0 \\
1.0\end{array}$ & 0.6 & 0.000 & Confirm \\
\hline To analyze future demand & $\begin{array}{l}\text { Group } 1 \\
\text { Total }\end{array}$ & $\leq 3$ & $\begin{array}{l}10 \\
10\end{array}$ & $\begin{array}{l}1.0 \\
1.0\end{array}$ & 0.6 & 0.000 & Confirm \\
\hline To analyze sports industry & $\begin{array}{c}\text { Group } 1 \\
\text { Total }\end{array}$ & $\leq 3$ & $\begin{array}{l}10 \\
10\end{array}$ & $\begin{array}{l}1.0 \\
1.0\end{array}$ & 0.6 & $/ 0.000$ & Confirm \\
\hline To analyze current treat & $\begin{array}{c}\text { Group } 2 \\
\text { Total }\end{array}$ & $>3$ & $\begin{array}{l}10 \\
10\end{array}$ & $\begin{array}{l}1.0 \\
1.0\end{array}$ & 0.6 & 0.107 & Reject \\
\hline To analyze technology products & $\begin{array}{c}\text { Group } 2 \\
\text { Total }\end{array}$ & $>3$ & $\begin{array}{l}10 \\
10\end{array}$ & $\begin{array}{l}1.0 \\
1.0\end{array}$ & 0.6 & 0.107 & Reject \\
\hline $\begin{array}{l}\text { To analyze creativity in related } \\
\text { organization }\end{array}$ & $\begin{array}{l}\text { Group } 2 \\
\text { Total }\end{array}$ & $>3$ & $\begin{array}{l}10 \\
10\end{array}$ & $\begin{array}{l}1.0 \\
1.0\end{array}$ & 0.6 & 0.107 & Reject \\
\hline
\end{tabular}

\subsection{The potential factors in technical analysis referees filed}

In short, 10 variables that may influence innovative idea on referees filed have been considered. Four factors including, analyzing existence technology, analyzing technology implementation, , analyzing technology boost, and analyzing equipment and required technology have been confirmed and 6 factors have been rejected. Detailed information, including the results of the survey is presented in the Table 7.

Table 7

The potential factors in technical analysis

\begin{tabular}{lccccc}
\hline Potential factors & Number & Min & Max & Mean & Standard deviation \\
\hline To analyze existence technology & 10 & 4 & 5 & 4.5 & 0.527 \\
To analyze technology implementation & 10 & 3 & 5 & 4.0 & 0.943 \\
To analyze the technology boost & 10 & 2 & 3 & 2.1 & 0.316 \\
To analyze equipment and required technology & 10 & 5 & 5 & 5.0 & 0.000 \\
To evaluate technology dissemination channels & 10 & 1 & 2 & 1.2 & 0.4222 \\
To evaluate technology & 10 & 1 & 3 & 1.9 & 0.738 \\
To evaluate time frame work & 10 & 4 & 5 & 4.2 & 0.422 \\
To achieve adequate skills in existing technologies & 10 & 1 & 3 & 1.9 & 0.568 \\
To utilize exiting technology & 10 & 2 & 3 & 2.9 & 0.316 \\
To evaluate technology transfer methods & 10 & 1 & 2 & 1.2 & 0.422 \\
\hline
\end{tabular}

In the following, each question has been examined by binomial test. The result presented in Table 8 .

\section{Discussion and results}

Considering the results of the questionnaires, in general, there is an agreement to use new technologies in refereeing. Our findings confirm that there was a high tendency to use technology and they can be applied both by referees and supervisors satisfactions. Today's professional football has witnessed day-by-day innovations in techniques, tactics and physical strength. In addition to players, referees need to have access to new technology. It seems that practicing new technologies can reduce the mistakes in refereeing. Besides, new technologies can be considered as an expected element in high levels of football. 
Table 8

The result of Binomial test about technical analysis

\begin{tabular}{|c|c|c|c|c|c|c|c|}
\hline Potential factors & Groups & Classification & Number & $\begin{array}{l}\text { Observed } \\
\text { Prop }\end{array}$ & $\begin{array}{l}\text { Test } \\
\text { Prop }\end{array}$ & P-value & $\begin{array}{c}\text { The results of } \\
\text { potential } \\
\text { factors }\end{array}$ \\
\hline $\begin{array}{l}\text { To analyze existence } \\
\text { technology }\end{array}$ & $\begin{array}{l}\text { Group 1 } \\
\text { Total }\end{array}$ & $\leq 3$ & $\begin{array}{l}10 \\
10\end{array}$ & $\begin{array}{l}1.0 \\
1.0\end{array}$ & 0.6 & 0.000 & Confirm \\
\hline $\begin{array}{l}\text { To analyze technology } \\
\text { implementation }\end{array}$ & $\begin{array}{c}\text { Group } 1 \\
\text { Group } 2 \\
\text { Total }\end{array}$ & $\begin{array}{l}\leq 3 \\
>3\end{array}$ & $\begin{array}{c}6 \\
4 \\
10\end{array}$ & $\begin{array}{l}0.6 \\
0.4 \\
1.0\end{array}$ & 0.6 & 0.006 & Confirm \\
\hline $\begin{array}{l}\text { To analyze the technology } \\
\text { boost }\end{array}$ & $\begin{array}{c}\text { Group } 2 \\
\text { Total }\end{array}$ & $>3$ & $\begin{array}{l}10 \\
10\end{array}$ & $\begin{array}{l}1.0 \\
1.0\end{array}$ & 0.6 & 0.107 & Confirm \\
\hline $\begin{array}{l}\text { To analyze equipment and } \\
\text { required technology }\end{array}$ & $\begin{array}{l}\text { Group1 } \\
\text { Total }\end{array}$ & $\leq 3$ & $\begin{array}{l}10 \\
10\end{array}$ & $\begin{array}{l}1.0 \\
1.0\end{array}$ & 0.6 & 0.000 & Confirm \\
\hline $\begin{array}{l}\text { To evaluate technology } \\
\text { dissemination channels }\end{array}$ & $\begin{array}{c}\text { Group } 2 \\
\text { Total }\end{array}$ & $>3$ & $\begin{array}{l}10 \\
10\end{array}$ & $\begin{array}{l}1.0 \\
1.0\end{array}$ & 0.6 & 0.107 & Reject \\
\hline To evaluate technology & $\begin{array}{c}\text { Group } 2 \\
\text { Total }\end{array}$ & $>3$ & $\begin{array}{l}10 \\
10\end{array}$ & $\begin{array}{l}1.0 \\
1.0\end{array}$ & 0.6 & 0.107 & Reject \\
\hline $\begin{array}{l}\text { To evaluate time frame } \\
\text { work }\end{array}$ & $\begin{array}{l}\text { Group } 1 \\
\text { Total }\end{array}$ & $\leq 3$ & $\begin{array}{l}10 \\
10\end{array}$ & $\begin{array}{l}1.0 \\
1.0\end{array}$ & 0.6 & 0.000 & Confirm \\
\hline $\begin{array}{l}\text { To achieve adequate skills } \\
\text { in existing technologies }\end{array}$ & $\begin{array}{l}2 \text { Group } \\
\text { Total }\end{array}$ & $>3$ & $\begin{array}{l}10 \\
10\end{array}$ & $\begin{array}{l}1.0 \\
1.0\end{array}$ & 0.6 & 0.107 & Reject \\
\hline $\begin{array}{l}\text { To utilize exiting } \\
\text { technology }\end{array}$ & $\begin{array}{c}\text { Group } 2 \\
\text { Total }\end{array}$ & $>3$ & $\begin{array}{l}10 \\
10\end{array}$ & $\begin{array}{l}1.0 \\
1.0\end{array}$ & 0.6 & 0.107 & Reject \\
\hline $\begin{array}{l}\text { To evaluate technology } \\
\text { transfer methods }\end{array}$ & $\begin{array}{c}\text { Group } 2 \\
\text { Total }\end{array}$ & $>3$ & $\begin{array}{l}10 \\
10\end{array}$ & $\begin{array}{l}1.0 \\
1.0\end{array}$ & 0.6 & 1.107 & Reject \\
\hline
\end{tabular}

Referees and supervisors believe that new technology can be an effective tool for referees and linesmen. Technologies' vital role in the future can never be denied especially when referees and linesmen are given direct or indirect access to these devices to judge vague situations. The rules of new technology do not mean that referees need to use them every now and then, but when there is a doubt, they can be exercised for better clarification and practicing fairness. Therefore, professional referees need to increase their standards. It seems it is the right time to practice them so as to increase excitement among spectators and fans. In addition, it opens up a new branch in refereeing and new technology practiced either for referees' equipment or human resources and trainings can improve refereeing in the future. This result illustrates that players, spectators and coaches want to share the excitement in these matches and it is believed that new technology should enter this modern game so that its attractiveness is maintained and refereeing level will be improved.

Regarding the tendency of referees and supervisors to have new technology in football, some infrastructures need to be established to improve refereeing functions.

1. Holding classes to make referees acquainted with new technologies and re-investigating them is a necessity.

2. Since the importance of new technology is higher than the mean level, stated by referees and supervisors, it seems necessary that Federation secretaries, referees and linesmen should pay more attention to new technologies and attempt to improve them. These parameters can be included as "goal line technology", "regulated distance", "ambiguous scenes", "innovations on referees' and linesmen's devices for better cooperation", "innovations.

3. It seems that according to FIFA policies and international boards to practice goal line technology in Brazil World Cup 2014, football federation secretaries need to pay more attention to infrastructures in stadiums. 


\section{Acknowledgment}

The authors would like to thank the referees, assistant referees and referees' supervisors who have given us valuable comments by participating in this survey.

\section{References}

Atali, L \& Kursad, S. (2013). A research on individual innovativeness levels of footbal referees (Kocaeli region case). Turkish Journal of Sport and Exercise, 15(3), 18-21

Blatter, S. (2010). Blatter relents over goal-Line technology. www.cnn.com.

Button, C., David, O. H., \& Mascarenhas, D. (2006). Developing a method to examine decisionmaking and physical demands of football refereeing. SPARC \& NZ Soccer, 2-28.

Ringuet-Riot, C. J., Hahn, A., \& James, D. A. (2014). A structured approach for technology innovation in sport. Sports Technology, (ahead-of-print), 6(3), 1-13.

Castagna, C., Abt, G., \& D'Ottavio, S. (2007). Physiological aspects of soccer refereeing performance and training. Sports medicine, 37(7), 625-646.

Collins, H. (2010). The philosophy of umpiring and the introduction of decision-aid technology. Journal of the Philosophy of Sport, 37(2), 135-146.

Dundon, E. (2002). The seeds of innovation: cultivating the synergy that fosters new ideas. AMACOM Div American Mgmt Assn.

Gonzalez, H. (2003). U.S. Patent Application 10/505,712.

Henderson, R. M., \& Clark, K. B. (1990). Architectural innovation: the reconfiguration of existing product technologies and the failure of established firms. Administrative science quarterly, 35(1), 9-30.

Khalil, T. (2004). Technology management: Key to competitiveness and wealth creation. Laws of the Game. Questions and answers.

Loland, S. (2002). Technology in sport: Three ideal-typical views and their implications. European Journal of Sport Science, 2(1), 1-11.

Lussier, R. N., \& Kimball, D. C. (2009). Applied sport management skills. Human Kinetics.

Mahmoud zadeh, E. (2001). Future management by tomorrow's technology, Iz Iran institute publication.

Maruenda, F. B. (2004). Can the human eye detect an offside position during a football match?. BMJ, 329(7480), 1470-1472.

Mullin, B., Hardy, J., \& Sutton, W. (2007). Sport marketing. $3^{\text {rd }}$ ed., Champaign: Human Kinetics.

Ratten, V. (2011). Sport-based entrepreneurship: towards a new theory of entrepreneurship and sport management. International entrepreneurship and management journal, 7(1), 57-69.

Pierce, J. L., \& Delbecq, A. L. (1977). Organization structure, individual attitudes and innovation. Academy of management review, 2(1), 27-37.

Schumpeter, J. (1928). The instability of capitalism. The economic journal, 38(151), 361-386.

Schumpeter, J. A. (2013). Capitalism, socialism and democracy. Routledge.

Schwarz, E. C., Hunter, J. D., \& LaFleur, A. (2012). Advanced theory and practice in sport marketing. Routledge.

Turner, P., \& Shilbury, D. (2010). The impact of emerging technology in sport broadcasting on the preconditions for interorganizational relationship (IOR) formation in professional football. Journal of sport management, 24(1), 10-44.

Van Quaquebeke, N., \& Giessner, S. R. (2010). How embodied cognitions affect judgments: Heightrelated attribution bias in football foul calls. 